\title{
Feature of fire resistance calculation of steel structures with intumescent coating
}

\author{
Alexey Vasilchenko ${ }^{1, *}$, Yuriy Otrosh ${ }^{1}$, Nikolay Adamenko ${ }^{2}$, Evgeny Doronin ${ }^{2}$, and Andrey \\ Kovalov $^{3}$ \\ ${ }^{1}$ National University of Civil Defence of Ukraine, Chernishevska str. 94, 61023, Kharkov, Ukraine \\ ${ }^{2}$ V. N. Karazin Kharkov National University, Svobody Sq. 4, 61022, Kharkov, Ukraine \\ ${ }^{3}$ Cherkassy Institute of Fire Safety of National University of Civil Defence of Ukraine, Onoprienko str. 8, \\ 18034, Cherkassy, Ukraine
}

\begin{abstract}
The problem of estimation of fire resistance of steel frame structures with intumescent coatings is considered. It implies that both physical properties of a covering (its thickness and structure) and mechanical properties of a metal structure change critically at heating. All above changes should be considered to maintain the standard values of fire resistance of a construction at calculation. Usually, known technical characteristics of fire resistance of intumescent coverings are used for estimation of fire resistance of steel structures with intumescent coverings. Importance of taking into account the influence of strength loss time at heating of a steel structure on calculation of fire resistance limit of system "intumescent fireproof coating - steel structure" is shown in the article. On an example of calculation of heating time to the critical temperature of steel columns and beams protected by intumescent coating, it is shown that own heating time of steel structures before they lose strength makes 10 to $16 \%$ from a settlement limit of fire resistance. This fact should be considered at the forecast of fire resistance of steel frame structures with intumescent coatings.
\end{abstract}

\section{Introduction}

Common use of steel structures in industrial frame buildings causes special requirements to their fire safety. The basic danger at heating of metal structures is their considerable deformations and fast loss of strength. This process can start with temperature of $350{ }^{\circ} \mathrm{C}$. An effective method of fire resistance of steel structures is use intumescent coatings. These coatings at contact with fire changes their structure, considerably increase in volume and forming a heat-protection layer $[1,2,3]$.

For maintenance of standard values of fire resistance of the steel frame structures protected by intumescent coatings, it is necessary to predict their characteristics taking into account power loadings. Here two approaches are possible:

\footnotetext{
*Corresponding author: avas2006@ukr.net
} 
- To estimate limits of fire resistance of the existing steel structures protected by intumescent coatings;

- To offer type and a thickness of a layer intumescent coatings for maintenance of demanded fire resistance of steel structures.

However, to define experimentally fire resistance of the large steel structures protected by intumescent coatings, being in construction structure it is almost impossible. Therefore the settlement estimation of their fire resistance limits is necessary.

The problem of settlement estimation consists that by working out of a method of problem solving it is necessary to consider such circumstances simultaneously: cardinal change at heating of properties of covering, its thickness and structure, and also change of properties of a metal structure [4].

Feature of intumescent fireproof coatings is the fast increase in their volume at heating and rough facing formation. This porous coating has low heat conductivity and protects the basic material from heating $[1,2]$. Existing calculation methods allow to count efficiency of such covering authentically. They consider time of warming up of an initial layer prior to the beginning of it intumescent and, then, time during which the intumescent layer is capable to protect a structure $[2,3,5]$. For steel structures in connection with high heat conductivity of metal the time of achievement of fire resistance limit consider the moment when temperature on border "covering - metal" becomes to equal critical temperature of a structure [6]. Values of fire resistance limits, calculated thus, do not consider time of warming up of actually metal structure which is in a stress state. Therefore they can be a little underestimated. It can lead to the over-expenditure of materials or the inexact forecast of behaviour of steel structures at a fire.

\section{Statement of a problem and its decision}

A work problem is calculation of warming up time of the steel structure protected by a intumescent coating, to critical temperature depending on an initial thickness of a covering.

It is possible to present a limit of fire resistance of a steel structure $\tau_{k p}$ as the sum of warming up times:

- Of a protective coat $\tau_{F b}$ to its temperature of intumescent $t_{F b}$;

- Of a intumescent layer $\tau_{F s}$ to critical temperature of a steel structure $t_{k s}$;

- Of a steel structure before loss of strength $\tau_{k s}$ :

$$
\tau_{k p}=\tau_{F b}+\tau_{F s}+\tau_{k S} .
$$

Calculation of fire resistance of a steel structure protected by a intumescent coating is based on the equation of heat conductivity of Fourier for the description of a onedimensional temperature field

$$
\rho c \frac{\partial t}{\partial \tau}=\frac{\partial}{\partial x}\left(\lambda \frac{\partial t}{\partial x}\right),
$$

where $\rho$-density of a material taking into account porosity; $c$ - specific thermal capacity of a material; $t$ - temperature; $\lambda$ - factor of heat conductivity of a material; $x$ - the coordinate directed on a thickness of a material; $\tau$ - time.

The equation (2) numerically solves by finite element method for a covering layer, both to it swelling, and after swelling, considering following boundary conditions:

a) For an external (heated up) surface of a fireproof covering boundary conditions of 3rd sort are accepted:

- Temperature of environment $\left(t_{F}\right)$ changes according to a curve of a "standard" fire: 


$$
t_{F}=345 \lg (8 \tau+1)+t_{0}
$$

- Heat transfer factor $(\alpha)$ from the gas environment to a structure surface equals:

$$
\alpha=29+5.75 \varepsilon_{\gamma} \frac{\left(\frac{t_{F}}{100}\right)^{4}-\left(\frac{t_{F b}}{100}\right)^{4}}{t_{F}-t_{F b}},
$$

where $\varepsilon_{\gamma}$ - the reduced emissivity factor of an irradiated surface;

b) For border between a covering and a steel structure conditions are accepted:

- Heat transfer factor $\alpha=0 \mathrm{~W} /\left(\mathrm{m}^{2} \cdot \mathrm{K}\right)$ (adiabatic wall);

- Boundary conditions:

$$
\begin{gathered}
\left.t\right|_{x=x_{\gamma}-0}=\left.t\right|_{x=x_{\gamma}+0} ; \\
\left.\lambda \frac{\partial t}{\partial x}\right|_{x=x_{\gamma}-0}=\left.\lambda \frac{\partial t}{\partial x}\right|_{x=x_{\gamma}+0} .
\end{gathered}
$$

For an example of calculation such steel structures warmed from 4 parties have been chosen: single-member axially-loaded columns and compound welded I-beams.

As a coating the fireproof intumescent structure "Terma" with such characteristics have been chosen: density $\rho=0.8 \mathrm{~kg} / \mathrm{m}^{3}$; effective factor of heat conductivity $\lambda_{e f}=0.05$ to $0.32 \mathrm{~W} /(\mathrm{m} \cdot \mathrm{K})$; intumescent factor $k_{s w}=40$; critical value of temperature $t_{F b}=177^{\circ} \mathrm{C}$.

At calculations following assumptions have been made:

- Warming up process for a local site as for a semi-infinite body with boundary conditions of 3 sorts was considered;

- Intumescent time of a protective film was not considered;

- It was supposed that thermal contact between a layer of covering both to swelling, and after swelling and a steel structure is ideal;

To calculate a column applies such method. Critical temperature find for each column, having set constant loading and having calculated factor of decrease in bearing ability at heating $\gamma_{T}$ :

$$
\gamma_{T}=\frac{N}{\varphi A_{K} R_{S} \gamma_{c}}
$$

where $N$ - loading on a column; $\varphi$ - factor of a longitudinal bend; $A_{K}$ - area of section of a column; $R_{S}$ - limit of resistance of a column material; $\gamma_{c}$ - working conditions factor.

Calculation of reduced thickness of a column $\delta_{k}$, does possible to define time of loss of strength [6-8].

Calculations for steel columns of various sections were spent. For each calculation loading on a column which provided critical temperature $t_{k S}=500{ }^{\circ} \mathrm{C}$ was accepted.

To calculate a beam applies such method. Factor of decrease in bearing ability at heating $\gamma_{T}$ (on which critical temperatures in the chosen sections were defined) was calculated under the formula:

$$
\gamma_{T}=\frac{M_{x}}{W_{x} R_{s}}
$$

where $M_{x}$ - the bending moment in settlement section at a cross-section bend, $\mathrm{kN} \cdot \mathrm{cm} ; W_{x}-$ modulus of section, $\mathrm{cm}^{3} ; R_{s}$ - ultimate strength of steel, $\mathrm{kN} / \mathrm{cm}^{2}$. 
Parameters of section of steel composite welded I-beams in length of $18 \mathrm{~m}, 21 \mathrm{~m}$ and $24 \mathrm{~m}$ calculated on [9]. Stiffening ribs are located with pitch of $1.5 \mathrm{~m}$. Beams are made of C345 steel, category 1 , with limiting resistance $R_{s}=45 \mathrm{kN} / \mathrm{cm}^{2}$. For comparability of results the distributed linear load on beams was accepted such to provide critical temperature $t_{k S}=500^{\circ} \mathrm{C}$.

Calculations were made in SCAD software. Received values were applied to an estimation of fire resistance limits on a method [8].

Results of calculations are shown in the table 1 .

Table 1. Settlement values of a fire resistance limit of the steel structures covered with fireproof intumescent structure "Terma".

\begin{tabular}{|c|c|c|c|c|c|c|c|}
\hline 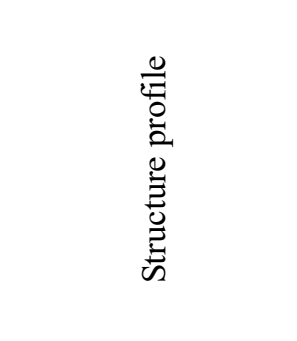 & 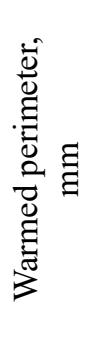 & 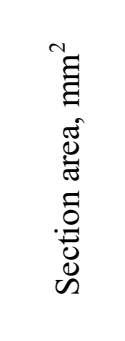 & 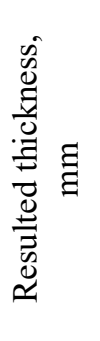 & 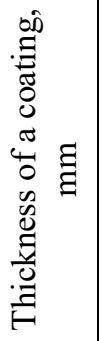 & 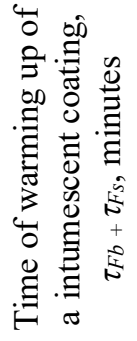 & 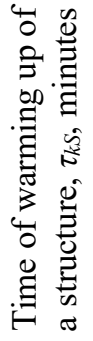 & 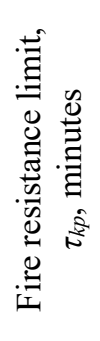 \\
\hline \multirow{2}{*}{$\begin{array}{l}\text { Column } \\
200 \times 200\end{array}$} & \multirow[t]{2}{*}{800} & \multirow[t]{2}{*}{3790} & \multirow[t]{2}{*}{4.74} & 1,0 & 58 & \multirow[t]{2}{*}{8} & 66 \\
\hline & & & & 2,0 & 68 & & 76 \\
\hline \multirow{2}{*}{$\begin{array}{ll}\text { Column } & \text { I-beam } \\
200 \times 100 \times 5.6 \times 8.5\end{array}$} & \multirow[t]{2}{*}{788} & \multirow[t]{2}{*}{2849} & \multirow[t]{2}{*}{3.61} & 1.0 & 44 & \multirow[t]{2}{*}{8} & 52 \\
\hline & & & & 2.0 & 62 & & 70 \\
\hline \multirow{2}{*}{$\begin{array}{l}\text { Column } \\
300 \times 140 \times 5.8 \times 8.5\end{array}$} & \multirow[t]{2}{*}{1140} & \multirow[t]{2}{*}{4192} & \multirow[t]{2}{*}{3.67} & 1.0 & 46 & \multirow[t]{2}{*}{8} & 54 \\
\hline & & & & 2.0 & 62 & & 70 \\
\hline \multirow{2}{*}{$\begin{array}{l}\text { Column } \\
395 \times 165 \times 7 \times 9.5\end{array}$} & \multirow[t]{2}{*}{1430} & \multirow[t]{2}{*}{6125} & \multirow[t]{2}{*}{4.28} & 1.0 & 56 & \multirow[t]{2}{*}{8} & 64 \\
\hline & & & & 2.0 & 66 & & 74 \\
\hline \multirow{2}{*}{$\begin{array}{l}\text { Column } \quad \text { I-beam } \\
492 \times 200 \times 8.8 \times 12\end{array}$} & \multirow[t]{2}{*}{1766} & \multirow[t]{2}{*}{9298} & \multirow[t]{2}{*}{5.26} & 1.0 & 59 & \multirow[t]{2}{*}{10} & 69 \\
\hline & & & & 2.0 & 70 & & 80 \\
\hline \multirow{2}{*}{$\begin{array}{l}\text { Column } \quad \text { H-beam } \\
196 \times 193 \times 6 \times 9\end{array}$} & \multirow[t]{2}{*}{1152} & \multirow[t]{2}{*}{3895} & \multirow[t]{2}{*}{3.38} & 1.0 & 30 & \multirow[t]{2}{*}{7} & 37 \\
\hline & & & & 2.0 & 60 & & 67 \\
\hline \multirow{2}{*}{$\begin{array}{l}\text { Column } \quad \text { H-beam } \\
291 \times 200 \times 8 \times 11\end{array}$} & \multirow[t]{2}{*}{1366} & \multirow[t]{2}{*}{6831} & 5 & 1.0 & 58 & 9 & 67 \\
\hline & & & & 2.0 & 70 & & 79 \\
\hline Column $\quad$ H-beam & 1957 & 12240 & 11 & 1.0 & 60 & 11 & 71 \\
\hline $388 \times 300 \times 9.5 \times 14$ & & & & 2.0 & 71 & & 82 \\
\hline Column $\quad$ H-beam & 2146 & 14570 & 12 & 1.0 & 60 & 12 & 72 \\
\hline $484 \times 300 \times 11 \times 15$ & & & & 2.0 & 72 & & 84 \\
\hline Structural I-Beam & 5784 & 88056 & 15.2 & 1.0 & 62 & 17 & 79 \\
\hline $\begin{array}{l}18 \mathrm{~m}: \\
2000 \times 446 \times 36 \times 18\end{array}$ & & & & 2.0 & 80 & & 97 \\
\hline Structural I-Beam & 6170 & 114300 & 18.5 & 1.0 & 65 & 19 & 84 \\
\hline $\begin{array}{l}21 \mathrm{~m}: \\
2100 \times 495 \times 45 \times 20\end{array}$ & & & & 2.0 & 85 & & 104 \\
\hline Structural I-Beam & 7422 & 168680 & 22.7 & 1.0 & 67 & 22 & 89 \\
\hline $\begin{array}{l}24 \mathrm{~m}: \\
2400 \times 655 \times 55 \times 28\end{array}$ & & & & 2.0 & 95 & & 117 \\
\hline
\end{tabular}

The resulted example shows that at estimation of fire resistance of steel structures protected by a intumescent coating "Terma", the time of warming up of actually steel 
structures before they will lose strength, makes 10 to $16 \%$ of a settlement limit of fire resistance. And this contribution will increase at increase in the resulted thickness of a structure. Also it is necessary to take into consideration that as the critical temperature of steel structures depends on loading rate on them and ultimate strength of steel these criteria should be considered at designing of fire protection.

\section{Conclusion}

Thus, it is shown on an example that at calculations of fire resistance limit of steel structure protected by intumescent coating, it is necessary to consider as time of warming up of this coating to critical temperature, and time of strength loss of actually steel structure at the reached temperature. This time depends also on parameters of the structure profile, of loading rate on it and of ultimate strength of steel.

\section{References}

1. G. Camino, S. Lomakin, Fire retardant materials/ Ed. by Horrocks A. and Price D. (CRC Press and Woodhead Publishing Ltd., Cambridge, 2001)

2. I.G. Romanenkov, V.N. Zigern-Korn, Ognestojkost' stroitel'nyh konstrukcij iz effektivnyh materialov (Strojizdat, Moskow, 1984)

3. S. V. Bazhenov, Pozharnaya bezopasnost', 5, 97-102 (2005)

4. O. Nekora, V. Slovynsky, S. Pozdieiev, MATEC Web of Conferences, 116, 02024, (2017).

5. D.E. Cagliostro, S.K. Riccitielio, K.J. Clare, J. Fire and Flammabie, 2, 205-291 (1975)

6. V.I. Golovanov, A.V. Ruzhinskij, Pozharo vzryvo bezopasnost', 2, 37-39 (1994)

7. N.M. Bessonov, T.Yu. Eremina, Yu.N. Dmitrieva, M.V. Krasheninnikova, Pozharnaya bezopasnost', 1, 22-28 (2007)

8. V.M. Rojtman, Inzhenernye resheniya po ocenke ognestojkosti proektiruemyh $i$ rekonstruiruemyh zdanij (Associaciya "Pozharnaya bezopasnost' i nauka", Moskow, 2001)

9. E.I. Belenya, V.A. Baldin, Metallicheskie konstrukcii. Obshchij kurs: Uchebnik dlya vuzov (Strojizdat, Moskow, 1986) 